\title{
ЗАРАЖЕНИЕ ДРУГОГО ЛИЦА ВИЧ-ИНФЕКЦИЕЙ ВСЛЕДСТВИЕ НЕНАДЛЕЖАЩЕГО ИСПОЛНЕНИЯ ПРЕДСТАВИТЕЛЕМ СФЕРЫ МЕДИЦИНСКИХ УСЛУГ СВОИХ ПРОФЕССИОНАЛЬНЫХ ОБЯЗАННОСТЕЙ: ПРОБЛЕМЫ ПРАВОВОГО РЕГУЛИРОВАНИЯ
}

\author{
(C) 2021 Хавжокова Залина Борисовна \\ кандидат юридических наук, доцент \\ Кабардино-Балкарский Государственный Университет, Кабардино-Балкарская Респ., Нальчик \\ E-mail: rado10101@rambler.ru \\ (c) 2021 Зумакулова Зарема Ахматовна \\ кандидат юридических наук, доцент \\ Кабардино-Балкарский Государственный Университет, Кабардино-Балкарская Респ., Нальчик \\ E-mail: zarema.zum@mail.ru \\ (c) 2021 Карамурзова Инна Барасбиевна \\ кандидат юридических наук, доцент \\ Кабардино-Балкарский Государственный Университет, Кабардино-Балкарская Респ., Нальчик \\ E-mail:07innka@mail.ru \\ (c) 2021 Кокова Диана Аслановна \\ кандидат юридических наук, доцент \\ Кабардино-Балкарский Государственный Университет, Кабардино-Балкарская Респ., Нальчик \\ E-mail:d.kokova@yandex.ru \\ (c) 2021 Бейтуганова Залина Хажмуратовна \\ старший преподаватель \\ Кабардино-Балкарский Государственный Университет, Кабардино-Балкарская Респ., Нальчик \\ E-mail: beituganova7890@gmail.com
}

В статье освещаются некоторые вопросы привлечения к ответственности в уголовном порядке за заражение представителем сферы медицинских услуг ВИЧ-инфекцией другого лица вследствие ненадлежащего исполнения своих профессиональных обязанностей.

Ключевые слова: здоровье человека, ВИЧ-инфекция, болезнь, преступление, медицинские услуги.

Неблагоприятные криминогенные изменения, низкий уровень оказания медицинской помощи и увеличивающееся количество профессиональных врачебных преступлений требуют расширения группы умышленных медицинских деяний посредством более детальной дифференциации ответственности и криминализации некоторых отступлений от профессиональных функций.

Врачи в период их обучения в учреждениях государственной или муниципальной системы здравоохранения имеют право на работу в этих учреждениях под контролем медицинского персонала, несущего ответственность за их профессиональную подготовку. Студенты высших и средних медицинских учебных заведений допускаются к участию в оказании ме- дицинской помощи гражданам в соответствии с программами обучения под контролем медицинского персонала, несущего ответственность за их профессиональную подготовку, в порядке, устанавливаемом Министерством здравоохранения Российской Федерации. Лица, не имеющие законченного высшего медицинского или фармацевтического образования, могут быть допущены к занятию медицинской или фармацевтической деятельностью в должностях работников со средним медицинским образованием в порядке, устанавливаемом Министерством здравоохранения Российской Федерации.

В настоящее время практически все виды врачебной деятельности, в том числе и те, которые необходимы к оказанию помощи в экстренных ситуациях, внесены в перечень Минздрава 
РФ, требующих обязательного наличия сертификата, однако, это не исключает ненадлежащего исполнения своих профессиональных обязанностей тем или иным представителем сферы медицинских услуг, в частности медицинским работником [1].

ВИЧ-инфекция - инфекционное заболевание человека, которое называлось СПИД (синдром приобретенного иммунодефицита) до открытия его возбудителя.

Следует разграничивать понятия «ВИЧ-инфекция» и СПИД. Последний употребляется для обозначения финальной стадии ВИЧ-инфекции. На этой стадии следует говорить о заболевании СПИД (т.е. ВИЧ-инфекцией в терминальной стадии). Вирус иммунодефицита человека имеет ряд существенных особенностей: ему присуща уникальная изменчивость, варианты вирусов выделяются не только у разных людей, но и у одного и того же человека в зависимости от стадии развития и даже на одной и той же стадии в тех или иных тканях; ВИЧ встраивается в хромосомы пораженной клетки, и инфекция, таким образом, приговаривает пораженный организм к пожизненному носительству вируса; ВИЧ единственный из регровирусов ведет к глубоким нарушениям всей иммунной системы больного; ВИЧ имеет фопизм - избирательное поражение определенной группы клеток, играющих чрезвычайно важную роль для нормального функционирования иммунной системы.

Сегодня инфекция, вызываемая вирусом иммунодефицита человека (ВИЧ) - ВИЧ-инфекция - рассматривается как одно из опаснейших заболеваний человека, в финале которого развивается смертельный синдром приобретенного иммунного дефицита (СПИД). В медицине термином «синдром» обозначают совокупность симптомов, объединенных единым механизмом развития. Такими общими симптомами при ВИЧ являются: нарушения иммунной системы, наличие различных сопутствующих инфекций, опухолей, высокой летальности (смертности) и др. Отметим, что под термином «иммунодефицит» понимается нарушение системы иммунитета, а под иммунитетом - состояние врожденной или приобретенной невосприимчивости организма к возбудителям инфекционных заболеваний. При ВИЧ-инфекции иммунодефицит вызывается проникновением в организм вирусов, способных не только повреждать, но и полностью блокировать иммунную систему. По- этому заразившийся ВИЧ легко может заболеть инфекционным или раковым заболеванием. Социальное значение ВИЧ-инфекции заключается в том, что в среднем через 10-11 лет после заражения ВИЧ неизбежно наступает гибель инфицированного. Это дает возможность утверждать, что основным непосредственным объектом в ст. 121 УК РФ выступает здоровье, дополнительным - жизнь человека, а под факультативным непосредственным объектом мы предлагаем понимать порядок осуществления профессиональной деятельности.

Объективная сторона заражения другого лица ВИЧ-инфекцией вследствие ненадлежащего исполнения медицинским работником своих профессиональных обязанностей формулируется в соответствии с принципом материального состава. Его следует признать оконченным в момент, когда происходит фактическое заражение пострадавшего ВИЧ-инфекцией.

Ранее нами отмечалось, что СПИД является терминальной (заключительной) стадией заболевания. Ей предшествуют стадия инкубации; стадия первичных проявлений (варианты течения: бессимптомная ВИЧ-инфекция, острая ВИЧ-инфекция без вторичных заболеваний, острая ВИЧ-инфекция с вторичными заболеваниями); субклиническая стадия и, наконец, стадия вторичных заболеваний [1]. Развитие ВИЧ-инфекции в организме потерпевшего на любой из вышеперечисленных стадий признается заражением, и виновный несет уголовную ответственность по ч.2 ст. 122 УК РФ.

Свою позицию относительно содержания факультативного объекта мы аргументируем тем, что деяние, предусмотренное ч. 4 ст. 122 УК РФ относится к числу преступлений, которые совершаются при осуществлении профессиональных функций с нарушением предписаний законодательства, современных требований науки и практики, положений профессиональной этики. Отсюда: совершаемое медицинским работником или иным специальным субъектом преступление посягает одновременно на здоровье человека и порядок осуществления возложенных на лицо обязанностей. Определение же второго объекта как факультативного обусловлено тем, что он закреплен только в квалифицированном составе, что, согласно уголовно-правовой доктрине, свидетельствует о его факультативном характере.

Обращаясь к анализу основного непосред- 
ственного объекта, подчеркнем, что в теории уголовного права нет единства мнений относительно сущности здоровья как объекта уголовноправовой охраны. Одни ученые (А.А.Пионтковский，Н.Д.Дурманов， Б.В.Здравомыслов и др.) рассматривают его как совокупность общественных отношений, «связь между людьми в процессе их совместной деятельности по поводу интересующих их предметов, явлений материального и нематериального мира, находящихся под охраной правовых норм» [1]. Другие авторы (например, С.Н. Таганцев, Н.И. Коржанский), придерживаясь теории интереса (блага), отмечают, что объектом преступления признаются те блага, на которые посягает преступник и которые охраняются уголовным законом. Данная позиция видится наиболее приемлемой, поскольку она позволяет рассматривать здоровье как нематериальную ценность, присущую каждому человеку с рождения, и не ставит его в зависимость от конкретных отношений, в которые вступает человек в процессе своего существования в обществе.

Представляется, что здоровье как объект уголовно-правовой охраны представляет собой нематериальное благо человека, право лица на полное физическое, душевное и социальное благополучие, имеющее абсолютный характер. Абсолютный характер предполагает, что праву лица на физическое и психическое благополучие корреспондирует обязанность всех остальных членов общества воздерживаться от действий, нарушающих это право. Это утверждение соответствует положениям российского законодательства. В частности, в п. 1 ст. 150 ГК здоровье входят в перечень принадлежащих гражданину от рождения нематериальных благ.

Рассматривая проблему заражения ВИЧ-инфекцией, нельзя обойти вниманием анализ примечания к ст. 122 УК РФ. Федеральным законом от 8 декабря 2003 года «О внесении изменений в УК РФ» законодатель предусмотрел примечание к статье 122 УК. В нем отмечается, что лицо, заведомо поставившее другое лицо в опасность заражения или заразившее ВИЧ-инфекцией, освобождается от уголовной ответственности в случае, если в отношении другого лица, поставленного в опасность заражения или зараженного ВИЧ-инфекцией, было сделано предупреждение о наличии этой болезни у предупредившего субъекта и другое лицо добровольно согласилось совершить действия, создавшие опасность зара- жения.

Социальная обусловленность, а равно законодательная точность рассматриваемой дефиниции вызывает ряд вопросов. В частности, формулировка примечания затрудняет анализ его содержания. С одной стороны, законодатель говорит об освобождении от уголовной ответственности, и буквальное толкование нормы позволяет предположить, что речь идет о специальных правилах освобождения от уголовной ответственности (частных случаях деятельного раскаяния). С другой стороны, императивный характер нормы позволяют утверждать, что примечание к ст. 122 УК РФ представляет собой специальное обстоятельство, исключающее преступность конкретного деяния. Иными словами, рассматриваемое примечание содержит в себе специальную разновидность непреступного причинения вреда с согласия жертвы.

С этой позиции важным является следующий вопрос: «Чем руководствовался законодатель, по сути декриминализируя «убийство в рассрочку»?». Общеизвестно, что ВИЧ-инфекция на современном этапе развития медицины не излечивается и представляет собой растянутое во времени убийство.

За последние десятилетия в мире возросло не только количество новых случаев венерических заболеваний, но и увеличивалось число самих болезней. По данным экспертов ВОЗ, в настоящее время насчитывается более 20 таких заболеваний:

- классические венерические болезни: сифилис; гонорея; мягкий шанкр (шанкроид); лимфогранулема венерическая; паховая гранулема;

- другие инфекции, передающиеся половым путем:

a) с преимущественным поражением половых органов: мочеполовой хламидиоз; мочеполовой трихомониаз; кандидозные вульвовапшиты; мочеполовой микоплазмоз; генитальный герпес; остроконечные бородавки; генитальный контагиозный моллюск; гарднереллезный вагинит; урогенитальный шигеллез гомосексуалистов; лобковый педикулез; чесотка;

б) с преимущественным поражением других органов: гепатиты В и C; цитомегалия; амебиаз (преимущественно у гомосексуалистов); лямблиоз.

Принятая Международным конгрессом Всемирной организации здравоохранения меж- 
дународная статистическая классификация болезней и проблем, связанных со здоровьем, выделяет болезни, передаваемые преимущественно половым путем [2].

Как мы можем наблюдать, постепенно в теории и на практике термин «венерические заболевания» заменяется понятием «болезни, передающиеся преимущественно половым путем». В связи с этим представляется небезосновательным вывод о необходимости замены терминологии и в уголовном законодательстве.

На общем фоне положительного влияния уголовного законодательства на укрепление и обеспечения безопасности основных благ и интересов личности, очевидно, что уголовноправовые средства и методы охраны жизни и здоровья пациента при производстве медицинского вмешательства далеки от совершенства, и нередко случаются ситуации, влекущие тяжелые последствия для здоровья человека, такие как заражение ВИЧ-инфекцией.

Специфика деяния, которое предусматривается ч. 4 ст. 122 УК РФ, заключается субъектном составе этого преступления. Под уголовную ответственность по этой норме подпадают определенные категории медицинских работников, в частности врачи, фельдшеры, медицинские сестры, которые, как правило, допускают случаи несоблюдения правил предосторожности при взаимодействии с ВИЧ-инфицированными больными, и как следствие, допускают заражение здоровых людей. При этом, обязательно следует установить факт совершения преступного деяния при исполнении представителем сферы медицинских услуг, в частности медицинским работником своих профессиональных обязанностей. Вина при совершении данного преступления может, по нашему мнению, выражаться как в форме умысла, так и неосторожности (только по легкомыслию).

Как известно, о типовой степени общественной опасности деяний свидетельствует много факторов, одним из них является корреляционная зависимость, то есть распространенность тех или иных преступлений в обществе.

Безусловно, государство несет ответственность за то, чтобы наилучшим образом сохранить, а также укрепить здоровье граждан. Государство обязано создавать гарантии, которые будут препятствовать появлению на рынке медицинских услуг неквалифицированных врачей и иных медицинских работников, не обладающих достаточными навыками для оказания медицинской помощи.

\section{Библиографический список}

1. Хавжокова З.Б., Зумакулова З.А., Карамурзова И.Б., Бейтуганова З.Х. Пределы правомерности причинения вреда при медицинском вмешательстве. // Вопросы экономики и права. М., 2019. С.12.

2. ВИЧ-инфекция и кожа. Учебник/ Под ред. О. Л. Иванова. М., 2002. С. 394-396.

3. Международная статистическая классификация болезней и проблем, связанных со здоровьем //http://www. d5.spb.ru/dictionary/mkb_10/Mkb_10_01_Infection.htm. 